\title{
Socialization Of Clean And Healthy Living Behaviors And Screening Of Non-Communicable Diseases In Efforts To Prevent The Pandemic Covid-19
}

\author{
Fitriani Kahar *1, Devi Etivia Purlinda ${ }^{2}$, Djoko Priyatno ${ }^{3}$, Ichsan \\ Hadipranoto $^{4}$, Rachmad Bayu Kuncara ${ }^{5}$ \\ 1,2,3,4,5 Lecturer Health of Analyst Department, Poltekkes Kemenkes Semarang Indonesia. \\ * Corresponding Author: \\ Email: fitrianikahar555@gmail.com
}

\begin{abstract}
.
Coronavirus (COV) is a large family of viruses that cause a slaughter starting from mild to severe symptoms. The disease caused by this virus is called Covid-19. One effort in the prevention of Covid-19's penis is to hold a health protocol and get clean life behavior and sehät in everyday life. Market Ganesha is one of the traditional markets that functions for buying and selling facilities where many people gather so that it becomes a means of repentance of Covid-19 if the community is a PHB pedagang and not applied health protocols. From the results of the activity it was seen that the community was enthusiastic in participating in the socialization of PHBS and alternately to carry out glucose blood pressure. This socialization activity is not only explained but but also socialization of Gerdik and behavior and obedient to the efforts of nitrance. This activity also completes one of the destinations, namely members of the health examination of residents in the form of blood pressure checks and laboratories (blood glucose examination). New) With the majority of respondents are in the category of 41-50 years and the majority of respondents with female sex. The conclusion is that the trader's society has a risk factor for suffering from the disease not menulus (PTM) especially and diabetes mellitus.
\end{abstract}

Keywords: PHBS Socializatio; Disease Not Menulus Screening, COVID-19 Prevention.

\section{INTRODUCTION}

The COVID-19 pandemic in Indonesia has caused many changes in everyday life. The COVID-19 pandemic emerged when the virus was known to spread from person to person in a short time and with symptoms such as high fever, cough, shortness of breath, lack of appetite and weakness. COVID-19 was first reported in Wuhan, Hubei, China in December 2019, and on March 11, 2020 the World Health Organization (WHO) declared that COVID-19 had become a worldwide pandemic disease [1]. Clinically, the representation of the presence of inflammation of the SARSCoV-2 virus in humans starts from the presence of asymptomatic presence to very severe pneumonia, with acute syndromes of respiratory distress, septic shock and multi-organ failure, leading to death. This is what causes an increase in threats during the COVID-19 pandemic, which causes the number of COVID-19 problems in residents to continue to increase [2].

Clean And Healthy Living Behaviors (PHBS) is a behavior to prevent infectious diseases such as dengue fever, diarrhea, and others. PHBS activities in public places such as markets, namely having to do behaviors that create PHBS-related 
public facilities such as washing hands with soap, using healthy latrines, disposing of garbage, not smoking, not smoking, not littering, giving mosquito larvae, etc [3]. Furthermore, it is stated that the result of the lack of knowledge of Clean and Healthy Behavior (PHBS) is a factor causing the high rate of transmission of infectious diseases such as dengue fever, diarrhea, worms [4]. Research data states that the implementation of PHBS in Tanjung Market is still low, of the 7 categories studied there are 3 categories that do not meet the requirements, namely fish traders do not use personal protective equipment, traders do not routinely check themselves regularly, and managers have not attended food and food hygiene courses [5]. This shows the importance of increasing knowledge of PBS in market traders.

Non-communicable diseases (PTM) in Indonesia are quite high, especially hypertension which affects 42.1 million (25.8\%) of the population, while diabetes affects 9 million people. Riskesdas data shows that only 30\% of hypertension and diabetes are diagnosed, and $70 \%$ have not been detected which in turn will have an impact on late medical treatment which can lead to complications, disability and premature death as well as increasing medical costs which have an impact on increasing economic burden [6].

Ministry of Health PTM prevention of Balitbangkes data from the Ministry of Health of the Republic of Indonesia states that non-communicable diseases are the highest cause of death in Indonesia in 2014, with hypertension in the third rank, namely $6.7 \%$ and followed by diabetes mellitus at 5.7\% [7]. Eriyani also mentioned that it is important to carry out early detection of risk factors for the community to increase community knowledge and understanding [8]. This shows the importance of early detection of non-communicable diseases before they become diseases causing complications. This non-communicable disease is also known as a comorbid factor of COVID-19.

The market is a place for buying and selling goods with more than one number of sellers, namely shops, traditional markets and others [9]. The market includes a public place which is a means where people gather and conduct interactions or relationships with each other. One form of this interaction is the meeting of buyers and sellers. The Ganesha market is no exception, which is a traditional market as a means of buying and selling [3]. The market is a means of buying and selling where many people gather so that it can be a means of transmitting COVID-19, including traders if they do not apply PHBS and health protocols are not applied.

Based on the regulation of the minister of health No. HK.01.07 / Menkes / $382 / 2020$ regarding health protocols for the public in public facilities in the context of preventing COVID-19 so that traders are also obliged to apply health protocols in the market to prevent transmission of COVID-19 [10]. Traders are a group of people who have the potential to contract and transmit COVID-19. Even though the government has implemented PSBB (Large-Scale Social Restrictions and Stay at Home) 
regulations, because the main job of the community to meet basic needs is trading, so they continue to carry out these activities as usual..

The results of observations in 2020 show that in Ganesha Market there are around 33 traders. The results show that it appears that the PHBS culture is still minimally carried out by the community, such as scattered garbage, sewage drains.

\section{METHODS}

The community service provider conducts community service activities using survey and interview methods to find out the problems of the traders at Ganesha Market. Laboratory tests were carried out for detection of non-communicable diseases through examination of blood glucose and blood pressure of the Ganesha Market traders as a screening for non-communicable diseases.

Audience The target of this activity is all traders in the Ganesha Pedurungan Semarang housing, totaling 33 traders. The method used in this community service activity is the following stages: The first stage is the preparatory stage, namely the planning of activities to be carried out. The planning process includes identification of needs, identification of the place of implementation, identification of potential and existing weaknesses by conducting interviews, discussions and asking for directions to the heads of the local RW.

The second stage is the implementation of activities together with the community and accompanied by the Head of the RW as planned while the Service and Team act as facilitators. The third stage is the implementation of monitoring and evaluation of the implementation of activities carried out by the Service Office and the Team and assisted by the Head of the RW.

In this activity, socialization activities were carried out aimed at increasing public knowledge and increasing awareness of PHBS so that traders can implement clean and healthy living behaviors in their daily life.

\section{RESULT AND DISCUSSION}

This community service activity is a socialization activity for PHBS and screening for non-communicable diseases through socialization on PHBS and checks on glucose and blood pressure as a ring for non-communicable diseases. The target of this activity is the merchant community in the Ganesha Market in Semarang City, amounting to 33 people. In general, this activity is carried out in 3 stages, namely the preparation stage (assessment and licensing activities), the activity implementation stage (PTM socialization and inspection activities), and the monitoring and evaluation stage of activities.

Community Service Program for the traders of Ganesha Market, Pedurungan Village, Semarang in the form of PHBS socialization activities in an effort to prevent the COVID-19 pandemic, prevention of non-communicable diseases (PTM) through 
screening for glucose and blood pressure measurements with a summary of the results of activities can be seen in table 1 as follows:

Table 1. Summary of Results of Community Service Activities

\begin{tabular}{llll}
\hline No. & $\begin{array}{l}\text { Description of } \\
\text { Work }\end{array}$ & $\begin{array}{l}\text { Result } \\
\text { Activities }\end{array}$ & Information \\
\hline 1 & $\begin{array}{l}\text { Socialization of } \\
\text { PHBS }\end{array}$ & $100 \%$ & Target \\
& & Tercapai \\
\hline 2 & Pemeriksaan & $100 \%$ & Target \\
& Tensi Darah & & Tercapai \\
\hline 3 & Pemeriksaan & $100 \%$ & Target \\
& Glukosa Darah & & Tercapai \\
\hline
\end{tabular}

Table 2. Indicators of the success of the Community Service Activities program

\begin{tabular}{|c|c|c|c|}
\hline No & Element & $\begin{array}{l}\text { Base line (Before } \\
\text { Community } \\
\text { Service) }\end{array}$ & $\begin{array}{c}\text { Achievement After Community } \\
\text { Service }\end{array}$ \\
\hline 1. & $\begin{array}{l}\text { Socialization of } \\
\text { PHBS }\end{array}$ & $\begin{array}{l}\text { Community } \\
\text { knowledge is still } \\
\text { low about PHBS }\end{array}$ & $\begin{array}{l}\text { Community knowledge is increasing } \\
\text { about PHBS and it is expected to apply } \\
\text { PHBS in their daily life }\end{array}$ \\
\hline 2. & $\begin{array}{c}\text { Blood Blood } \\
\text { Pressure Check }\end{array}$ & $\begin{array}{l}\text { Do not know the } \\
\text { blood pressure } \\
\text { value }\end{array}$ & $\begin{array}{l}\text { All traders have known the blood } \\
\text { blood pressure value. }\end{array}$ \\
\hline 3. & $\begin{array}{l}\text { Blood Glucose } \\
\text { Examination }\end{array}$ & $\begin{array}{l}\text { Blood Glucose } \\
\text { Examination }\end{array}$ & $\begin{array}{l}\text { All traders have known the value of } \\
\text { blood pressure }\end{array}$ \\
\hline 4. & $\begin{array}{c}\text { Routinely } \\
\text { check blood } \\
\text { glucose levels } \\
\text { and blood } \\
\text { pressure }\end{array}$ & Not routine & $\begin{array}{l}\text { Routine and accustomed and become a } \\
\text { necessity for themselves }\end{array}$ \\
\hline
\end{tabular}

\section{a. Target Audience}

Audience The target of this activity is all traders in the Ganesha Pedurungan Semarang housing, totaling 33 people.

\section{b. Related parties}

The parties involved in this activity are the Head of the Pedurungan urban village office and the Chairperson of the RW IV Perumahan Ganesha, Pedurungan Village, who have given permission as well as assistance during the implementation of community service. The head of the health analyst department, which has provided laboratory equipment facilities and infrastructure for health examination activities. The Service Team which is the executor of the activity, as well as the traders as the audience and the object of the medical examination. 


\section{c. Purpose and Benefits of Activities}

The goals and benefits of this service activity are:

1. The existence of PHBS socialization activities to the merchant community, namely increasing public knowledge and awareness of the importance of implementing PHBS in everyday life not only when trading so that they can avoid transmission of COVID19.

2. Screening for non-communicable diseases aims to enable the merchant community to detect non-communicable diseases early, so that people can continue to control their health conditions, so that treatment can be carried out early on. Can detect risk factors for co-morbid COVID-19.

\section{d. Implementation of Activities}

PKM activities of PHBS socialization activities in an effort to prevent the COVID-19 pandemic, prevention of non-communicable diseases (PTM) through screening for glucose and blood pressure measurements are carried out in several stages of activities, namely: Preparation Stage, Implementation Stage, and Evaluation Stage.

In the preparation stage, an assessment was carried out to the RW Chair in Ganesha Housing and looking for information regarding a number of traders at Ganesha Market and to see the public's response to the COVID-19 Pandemic. The next step is to give permission to the head of the RW housing Ganesha and to the local government, namely the Pedurungan Village Office to get approval for the PKM activities that will be carried out.

At the implementation stage, counseling was held on Friday, 16 October 2020 at 09.00-11.30 WITA at the Ganesha Market, Pedurungan Village, Pedurungan District, Semarang. Interventions carried out were in the form of counseling and direct PHBS practices such as proper and correct hand washing, disposing of garbage in its place and implementing health protocols (wearing masks, washing hands with soap, and maintaining distance). Carrying out blood pressure checking activities with a tension meter and checking blood glucose while using the POCT method.

In the monitoring and evaluation stage, it was seen that during the extension process about PHBS, all traders paid close attention. Monitor non-communicable disease checks. After completing the delivery of the material, it is continued with the practice of washing hands and disposing of trash in its place, and implementing health protocols. The merchants enthusiastically and enthusiastically took turns in carrying out the practice of washing hands and disposing of garbage in the proper place and taking turns in checking blood pressure and blood glucose.

In the results of observations at the Ganesha market, which is still a problem, namely traders and workers have not behaved clean and healthy in the market environment, this can be seen from the observations of the servants showing that traders when trading smoke, littering, spitting carelessly which can affect health. Tatang Roni said that people's behavior that is not clean and healthy will affect their 
health. Regarding the implementation of health protocols by traders, it is seen that the traders adhere to health protocols such as wearing masks, washing hands with soap, and maintaining good distance between traders and visitors. The traders are seen in their respective stalls as a form of maintaining their distance and not crowding the market while in the market [11].

\section{d. PHBS Socialization Activities}

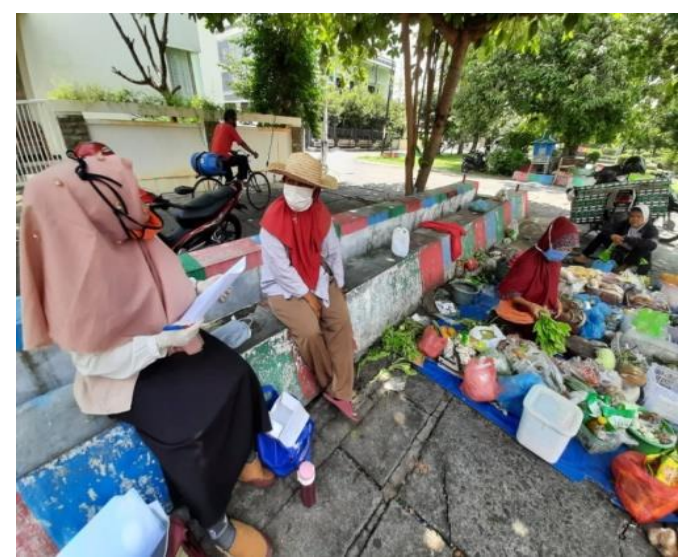

Fig 1. PHBS socialization activities to Ganesha Market traders by applying the Health Protocol.

This socialization activity was carried out individually and in turn with traders before the examination was carried out because this activity was carried out during the COVID-19 pandemic. The rule during the COVID-19 pandemic is not to create crowdcausing activities, and it is mandatory to implement health protocols.

This socialization is expected to raise public awareness about a clean and healthy lifestyle so that it is hoped that it can be realized in community behavior. Andriansyah said that the PHBS counseling program and practices are very important, especially for rural communities in order to increase awareness of the importance of pursuing a clean and healthy lifestyle [12]. This is also in line with the PHBS empowerment activities carried out by Patilaiya, who revealed that there was an increase in household and SD students' knowledge about PHBS and all students were also able to practice washing hands properly after PHBS counseling was carried out [13]. Furthermore, it was stated that to support the PHBS program, routine activities regarding PHBS are needed [14]. This activity is expected to have an impact on improving the health status of the community who sells Ganesha Market in Semarang City.

\section{e. Non-Communicable Disease Detection Activities}

The results of monitoring of early detection of non-communicable diseases in the community are carried out to detect non-communicable diseases early as a co-morbid factor of COVID-19 in the community so that early treatment can be carried out. The percentage of examination results can be seen in the table below as follows: 
Table. 3. Percentage of Early Detection of Hypertension by measuring blood pressure

\begin{tabular}{clcc}
\hline NO & $\begin{array}{l}\text { Hypertension } \\
\text { Category }\end{array}$ & F & $(\%)$ \\
\hline 1 & Normal $(<120)$ & 3 & 9 \\
\hline 2 & $\begin{array}{l}\text { Prehipertensi } \\
(120-139)\end{array}$ & 20 & 64 \\
\hline 3 & $\begin{array}{l}\text { Hipertensi Tk I } \\
(120-139)\end{array}$ & 6 & 18 \\
\hline 4 & $\begin{array}{l}\text { Hipertensi Tk II } \\
(120-139)\end{array}$ & 4 & 12 \\
\hline \multicolumn{1}{c}{ Total } & 33 & 100 \\
\hline
\end{tabular}

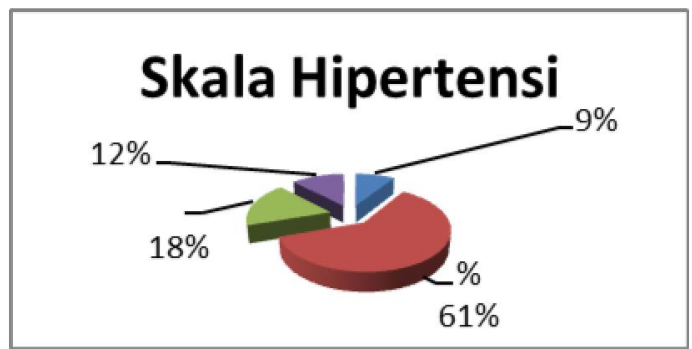

Fig 2. Percentage of Early Detection of Hypertension by measuring blood pressure

Based on table 3 for hypertension examination, the results obtained are in the category of hypertension disease, from a total of 33 traders examined, there were 3 people (9\%) in the normal category, 20 people (64\%) in the pre hypertension category, 6 people (18\%) with the TK I hypertension category, 4 people (12\%) with the TK II Hypertension category, so it can be concluded that the majority of traders are at risk of having hypertension because the majority of people's conditions are in the pre hypertension category, which means that people have the potential to suffer from hypertension. From these results, it is hoped that the need for monitoring and follow-up efforts by the community in order to implement a healthy and routine lifestyle to check themselves regularly to control blood pressure in health services in order to prevent hypertension in the community. This result is in line with the previous public examination, namely that the majority of respondents were in the hypertension type I classification, namely 57 respondents [15].

Table. 4. Percentage of Diabetes Mellitus Early Detection by measuring blood glucose

\begin{tabular}{clcc}
\hline NO & Category DM & F & $\mathbf{( \% )}$ \\
\hline 1 & Normal $(<90)$ & 8 & 32 \\
\hline 2 & Pre DM $(90-199)$ & 16 & 64 \\
\hline 3 & DM $(>90)$ & 1 & 4 \\
\hline & Total & 25 & 100 \\
\hline
\end{tabular}




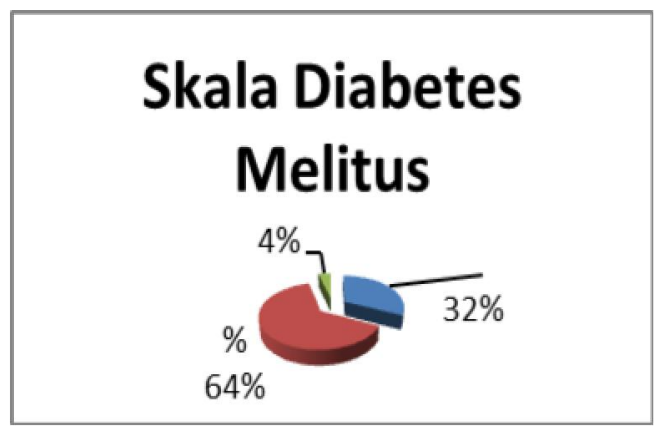

Fig 3. Prosentase Deteksi Dini Penyakit Diabetes Mellitus melalui pengukuran glukosa darah

Based on table 4 for blood glucose examination, the results were obtained, namely in the DM disease category, from a total of 25 traders examined, there were 8 people $(32 \%)$ in the normal category, 16 people (64\%) with the uncertain category of DM / prediabetes, and 1 people (4\%) with the DM category, so it can be concluded that the majority of traders are included in the Pre DM category so that special attention is needed by the community and to the government to prevent DM disease, because if preventive measures are not taken by the community then this will potentially become a disease DM. What people who have the potential to do DM can do is to maintain a healthy lifestyle.

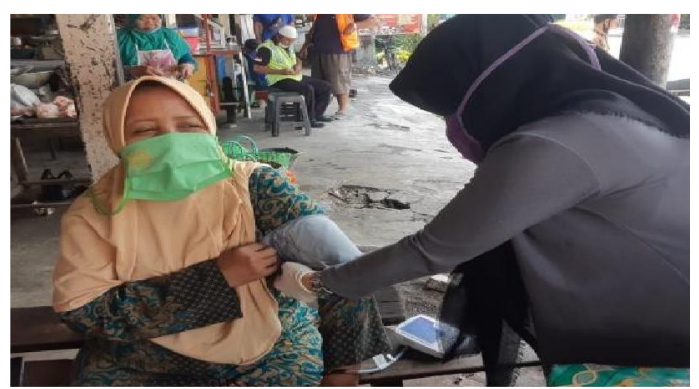

Fig 4. Screening of Non-Communicable Diseases (PTM) through blood pressure examination

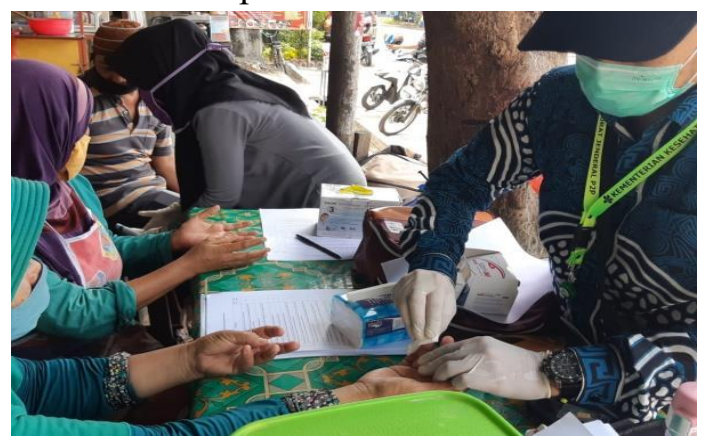

Fig 5. Non-Communicable Disease Screening (PTM) through blood glucose examination 


\section{f. Target dan Output}

This Community Service Program, which is the target for its achievement, is the market trader who sells at the Ganesha Pedurungan Housing Complex, Semarang with a total of 33 people.

This counseling is expected to provide good and correct information to the merchant community regarding clean and healthy living habits in the market, so that a clean and healthy market environment can be created and free from the spread of the COVID-19 disease. Aspects that can be obtained by conducting blood pressure checks and blood glucose checks to detect non-communicable diseases in the local community as an early detection effort, and hypertension and diabetes mellitus are comorbid diseases which are factors that facilitate the occurrence of COVID-19 so that efforts to prevent Covid-19 can be done. This activity also seeks to independently prevent the transmission of Covid-19 so that at least "JOGO TONGGO" can be carried out

The essence of the target output of this Community Service activity is a solution to the problems faced by partners through a collaborative approach with the Head of the RW and the Head of the local RT so that they can apply PHBS in the market and in daily life and continue to apply health protocols in the market. The public can find out the health conditions related to hypertension and diabetes mellitus with this activity. This was done as an effort to prevent COVID-19.

To maximize the role in preventing the transmission of COVID-19, it is necessary to conduct socialization in getting used to the Healthy Living Community Movement (GERMAS) as an effort to increase awareness, willingness and ability for everyone to live healthy so that the highest level of public health can be realized [16]. The GERMAS Community Partnership Program through socialization, training in planting horticultural gymnastics, consumption of fruits and vegetables, and self-examination at health services can be carried out as an effort to prevent non-communicable diseases [17]. The Program to Prevent PTM as an activity to develop PHBS through gymnastics, health education and health checks can also be carried out to increase public awareness of Non-Communicable Diseases so that this can become a routine activity to be carried out [18].

The results of interviews and observations to the merchant community indicated that the community had not routinely carried out regular health checks. They feel reluctant to come to health facilities, especially in this pandemic situation, they feel afraid if they contract COVID-19 because they know that health facilities are crowded places or are seen by many people. It has been regulated in the Republic of Indonesia's Minister of Health Decree No. 519 / Menkes / SK / VI / 2008, that traders must undergo periodic health checks at least every 6 months, but from the results of interviews with traders they say that they have never been subjected to periodic health checks at least once every 6 months [19]. This examination is useful for detecting whether there are traders suffering from non-communicable diseases so that they can 
be treated immediately so that the disease does not spread and can monitor the health of the traders.

There are two risk factors for PTM (hypertension and DM), namely, risk factors that cannot be changed or risk factors inherent in people with hypertension such as: age, gender, and genetics, and risk factors caused by unhealthy behavior of people with hypertension, among others: smoking, low fiber diet, dyslipidemia, excessive salt consumption, lack of physical activity, stress, obesity, alcohol consumption [20]. As mentioned also by Indriyawati et al, that a lifestyle that tends to be less active, obesity, smoking, alcohol consumption and minimal consumption of vegetables and fruit will be the risk of PTM disease. Furthermore, it was stated that PTM control can be done through modification of risk factors through behavior changes called CERDIK which is carried out routinely and continuously [21] .

To manage hypertension, including other non-communicable diseases such as DM, the Ministry of Health has made policies, namely: (1) Developing and strengthening active early detection of hypertension (screening), (2) Providing increased public access to PTM Posbindu activities as early detection services, ( 3) Providing increased access for patients to hypertension treatment (PTM) by revitalizing health centers through increasing professional and competent health personnel resources in efforts to control PTM, especially PTM management in basic health service facilities such as Puskesmas; Improvement of PTM control service management in a comprehensive (especially promotive and preventive) and holistic manner[22].

There are several government programs to urge and invite all people to prevent and control non-communicable diseases through the Healthy Living Community Movement (GERMAS) with a focus on increasing the behavior of CERDIK and PATUH, starting with oneself, family and the surrounding community. The definition of intelligent behavior is regular health checks, get rid of cigarette smoke, exercise diligently, have a balanced diet, have adequate rest, and manage stress. Whereas COMPLY, check your health regularly and follow doctor's recommendations, overcome diseases with proper and regular treatment, keep a diet with balanced nutrition, try to do physical activity safely, avoid cigarette smoke, alcohol and other carcinogenic (cancer-causing) substances. COMPLIANCE behavior must be done for those who already have PTM [23].

By looking at the facts in the field that the community of traders still does not routinely check their health conditions so it is suggested that there should be promotional and preventive efforts towards PTM, so that the GERMAS, CERDIK and PATUH programs need to be promoted to the community to increase public awareness and motivate the community to adopt a clean and healthy lifestyle. healthy, and motivates people to regularly check their health conditions. It is necessary to carry out sustainable PHBS resocialization to the merchant community so that people always apply PHBS in their daily life as an effort to prevent the transmission of COVID-19. 


\section{CONCLUSION}

a. Community service activities run smoothly and on time. PKM activities can add insight and knowledge to the community regarding PHBS so as to provide support in implementing the Healthy Living Movement for the community through a clean and healthy lifestyle and implementing health protocols in an effort to prevent the spread of COVID-19.

b. From the results of the tests carried out for two categories, namely blood pressure and blood glucose tests, the results were in the DM disease category, so out of a total of 25 traders examined, there were 8 people (32\%) in the normal category, 16 people (64\%) with the category. DM is not certain, and 1 person (4\%) is in the DM category, so it can be concluded that the majority of traders are in the prediabetes category. For hypertension examination, the results obtained were in the hypertension category, from a total of 33 traders examined, there were 3 people $(9 \%)$ in the normal category, 20 people $(64 \%)$ in the pre hypertension category, 6 people $(18 \%)$ with the hypertension category. TK I, 4 people $(12 \%)$ with the category TK II Hypertension, so it can be concluded that the majority of traders are included in the pre hypertension category. The conclusion is that the merchant community has risk factors for contracting Non-Communicable Diseases (PTM), especially hypertension and diabetes mellitus.

\section{ACKNOWLEDGMENTS}

Thank you to the Head of the Pedurungan urban village office and the Chairman of the RW IV Ganesha Housing, Pedurungan Village, who have given permission as well as assistance during the implementation of community service, the Service Team, and all parties involved in the Community Service Community Partnership Program.

\section{REFERENCES}

[1] J. L. Andrews, L. Foulkes, and S. J. Blakemore, "Peer Influence in Adolescence: Public - Health Implications for COVID-19," Trends Cogn. Sci., vol. 24, no. 8, pp. 585-587., 2020.

[2] N. P. E. D. Yanti, I. M. A. D. P. Nugraha, G. A. Wisnawa, N. P. D. Agustina, and N. P. A. Diantari, "Public Knowledge about Covid-19 and Public Behavior During the Covid-19 Pandemic," J. Keperawatan Jiwa, vol. 8, no. 4, p. 491, 2020.

[3] Kemenkes-RI, Peraturan Menteri Kesehatan Republik Indonesia No: 2269/MENKES/PER/XI/2011 Pedoman Pembinaan Perilaku Hidup Bersih dan Sehat (PHBS). Jakarta: Kemenkes RI, 2011.

[4] S. M. Ayu, A. Kurniawan, M. A. Y. Ahsan, and A. K. Anam, "PENINGKATAN KESEHATAN MELALUI PERILAKU HIDUP BERSIH DAN SEHAT (PHBS) SEJAK DINI DI DESA HARGOMULYO GEDANGSARI GUNUNG KIDUL," $\boldsymbol{J}$. Pemberdaya. Publ. Has. Pengabdi. Kpd. Masy., vol. 2, no. 1, pp. 20-27, 2018.

[5] K. Nurcahaya, A. D. Moelyaningrum, and P. T. Ningrum, "Identifikasi Sanitasi Pasar di 
Kabupaten Jember (Studi di Pasar Tanjung Jember)," e-Jurnal Pustaka Kesehat., vol. 2, no. No. 2, pp. 285-292, 2014.

[6] Kemenkes-RI, "PTM Pencegahan dan Pengendalian Penyakit Tidak Menular di Indonesia," in Booklet, Jakarta: Kementrian Kesehatan RI, 2016.

[7] Ditjen Pencegahan dan Pengendalian Penyakit Kementrian Kesehatan RI, "Kebijakan Pencegahan Dan Pengendalian Penyakit Tidak Menular," Jakarta: Kementrian Kesehatan RI, 2018.

[8] T. Eriyani, Witdiawati, and R. Udin, "Deteksi Dini Faktor Resiko Penyakit Tidak Menular Di Rw 12 Desa Jayaraga Kecamatan Tarogong Kidul Kabupaten Garut,” J. Kreat. Pengabdi. Kpd. Masy., vol. 3, no. April, pp. 135-141, 2020.

[9] Peraturan Presiden RI, "PERATURAN PRESIDEN REPUBLIK INDONESIA NOMOR 112 TAHUN 2007 PENATAAN DAN PEMBINAAN PASAR TRADISIONAL TENTANG PUSAT PERBELANJAAN DAN TOKO MODERN," 2007.

[10] Kemenkes-RI, “Permenkes RI KMK No. HK.01.07/MENKES/382/2020,” Peraturan Menteri Kesehatan Republik Indonesia, vol. Nomor 9, no. Pedoman Pembatasan Sosial Berskala Besar dalam Rangka Percepatan Penanganan Corona Virus DIsease 2019 (COVID-19). pp. 2-6, 2020.

[11] R. S. Tatang, T. Ruhmawati, and S. Denny, "Hubungan Pendidikan dan Penghasilan dengan Perilaku Hidup Bersih dan Sehat," J. Kesehat. Lingkung. Indones., vol. 12, no. 1, 2013.

[12] Y. Andriansyah and D. N. Rahmantari, "Penyuluhan Dan Praktik Phbs ( Perilaku Hidup Bersih," Inov. dan Kewirausahaan, vol. 2, no. 1, pp. 45-50, 2013.

[13] H. La Patilaiya and H. Rahman, "Pemberdayaan Masyarakat Melalui Penyuluhan Perilaku Hidup Bersih dan Sehat untuk Meningkatkan Kualitas Kesehatan Masyarakat," JPPM (Jurnal Pengabdi. dan Pemberdaya. Masyarakat), vol. 2, no. 2, pp. 251-258, 2018.

[14] N. Karlina, B. Rusli, E. A. Muhtar, and Candradewini, "Sosialisasi Pembangunan Perumahan \& Permukiman Berbasis Komunitas dan Perilaku Hidup Bersih dan Sehat di Desa Pulosari, Kecamatan Pangalengan, Kabupaten Bandung," Kumawula J. Pengabdi. Kpd. Masy., vol. 3, no. 2, pp. 154-162, 2020.

[15] Y. Susanti, Anita, and D. Y. A. Santoso, "PERILAKU CERDIK PENDERITA HIPERTENSI DIMASA PANDEMI COVID 19," J. Keperawatan, vol. 13, no. 1, pp. 61-76, 2021.

[16] N. Indriyawati, M. Jannah, and B. Saptiwi, "Poltekkes Kemenkes Semarang Wujudkan Gaya Hidup Sehat Melalui Sosialisasi Gerakan Masyarakat Hidup Sehat (Germas) Di Jawa Tengah," Link, vol. 15, no. 1, p. 42, 2019.

[17] E. Junita, E. Y. Handayani, and L. N. Alfiah, "GERMAS ( Healthy Life Society Movement ) IN RAMBAH HILIR VILlage,” Kumawula J. Pengabdi. Kpd. Masy., vol. 3, no. 1, pp. 100-105, 2020.

[18] U. Rosidin, Witdiawati, and U. Sumarna, "BERAKSI CEGAH PENYAKIT TIDAK MENULAR,” Kumawula J. Pengabdi. Kpd. Masy., vol. 3, no. 3, pp. 507-514, 2020.

[19] Departemen Kesehatan RI, "Pedoman Pengendalian Diabetes Melitus dan Penyakit Metabolik.” Departemen Kesehatan RI, Jakarta, pp. 1-41, 2008.

[20] Kemenkes-RI, "Faktor Risiko Hipertensi. Direktorat Pencegahan dan Pengendalian 
Penyakit Tidak Menular. Dirjen Pencegahan dan Pengendalian Penyakit,” 2018. [Online]. Available: http://p2ptm.kemkes.go.id/infographic-p2ptm/hipertensi-penyakitjantung-dan-pembuluh-darah/faktor-risiko-hipertensi. [Accessed: 02-Feb-2021].

[21] N. Indriyawati, Widodo, P. D, and Jannah M, "Skrining Dan Pendampingan Pencegahan Penyakit Tidak Menular Di Masyarakat," Link, vol. 14, no. 1, p. 50, 2018.

[22] Kemenkes-RI, "Hipertensi dan Penanganannya," Direktorat Pencegahan dan Pengendalian Penyakit Tidak Menular. Dirjen Pencegahan dan Pengendalian Penyakit., 2017. [Online]. Available: http://p2ptm.kemkes.go.id/artikelsehat/hipertensi-dan-penanganannya. [Accessed: 01-Feb-2021].

[23] Kemenkes-RI, "Hari Hipertensi Dunia 2019: 'Know Your Number, Kendalikan Tekanan Darahmu dengan CERDIK.,", 2019. [Online]. Available: http://p2ptm.kemkes.go.id/artikel-sehat/hipertensi-dan- penanganannya. [Accessed: 01Feb-2021]. 